$\gamma$

LA-11066-MS, Vol. II

Received by GST!

SÉP 011987

\title{
REVIEW OF INTERNATIONAL GEOTHERMAL
} ACTIVITIES AND ASSESSMENT OF

\section{U. S. INDUSTRY OPPORTUNITIES}

\section{Summary Report}

\section{LO NOT MICROFILM \\ COVER}
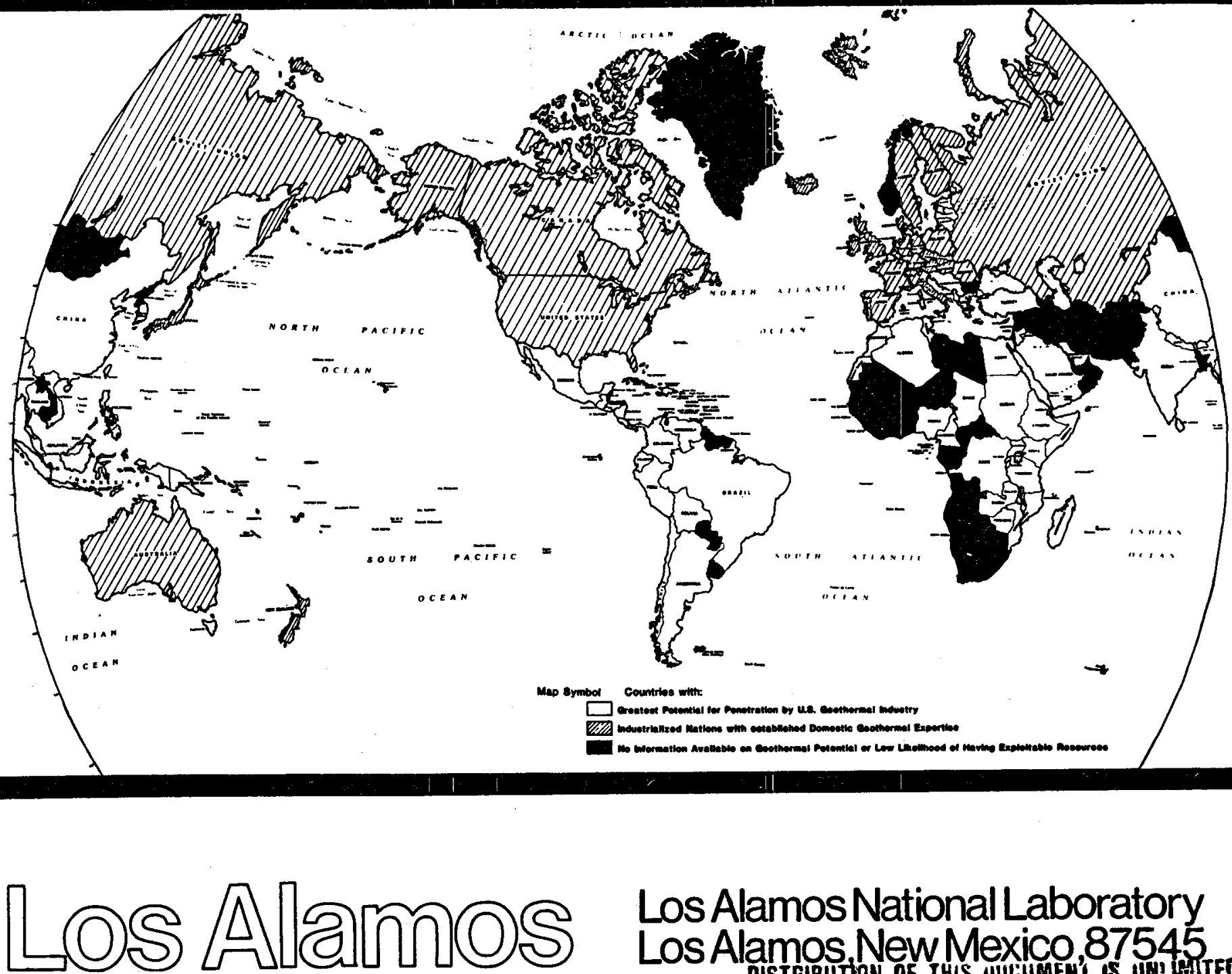

\section{Los Alamos National Laboratory Los Alamos.New Mexico 87545

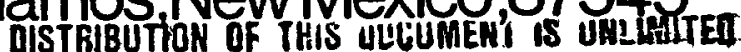




\section{DISCLAIMER}

This report was prepared as an account of work sponsored by an agency of the United States Government. Neither the United States Government nor any agency Thereof, nor any of their employees, makes any warranty, express or implied, or assumes any legal liability or responsibility for the accuracy, completeness, or usefulness of any information, apparatus, product, or process disclosed, or represents that its use would not infringe privately owned rights. Reference herein to any specific commercial product, process, or service by trade name, trademark, manufacturer, or otherwise does not necessarily constitute or imply its endorsement, recommendation, or favoring by the United States Government or any agency thereof. The views and opinions of authors expressed herein do not necessarily state or reflect those of the United States Government or any agency thereof. 


\section{DISCLAIMER}

Portions of this document may be illegible in electronic image products. Images are produced from the best available original document. 
An Affirmative Action/Equal Opportunity Employer

\section{DISCLAIMER}

This report was prepared as an account of work sponsored by an agency of the United States Government. Neither the United States Government nor any agency thereof, nor any of their employees, makes any warranty, express or implied, or assumes any legal liability or responsibility for the accuracy, completeness, or usefulness of any information, apparatus, product, or process disclosed, or represents that its use would not infringe privately owned rights. Reference herein to any specific commercial product, process, or service by trade name, trademark, manufacturer, or otherwise, does not necessarily constitute or imply its endorsement, recommendation, or favoring by the United States Government or any agency thereof. The views and opinions of authors expressed herein do not necessarily state or reflect those of the United States

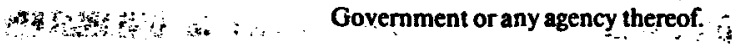


LA--11066-MS-Vol.II

DE87 014019
LA-11066-MS, Vol. II

UC-66

Issued: August 1987

\section{Review of International Geothermal Activities and Assessment of U.S. Industry Opportunities \\ Summary Report}

Report prepared by

Meridian Corporation

4300 King Street, Suite 400

Alexandria, Virginia 22302

\section{MASTER}

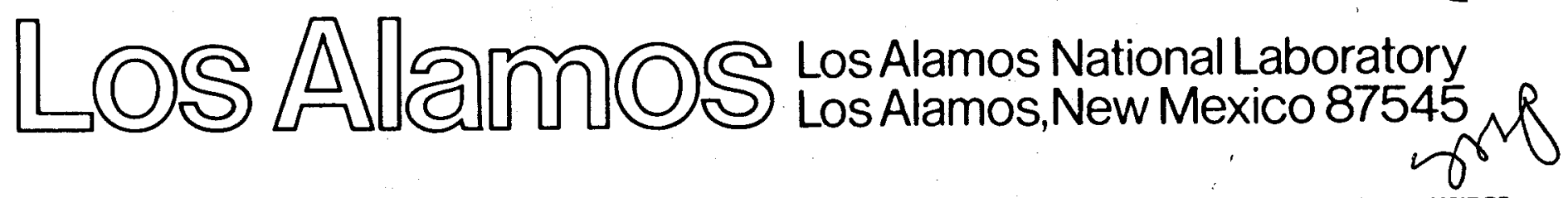




\section{PREFACE}

The report contained herein is a summary of the key information and data contained in the full report entitled: "Review of International Geothermal Activities and Assessment of U.S. Industry Opportunities." The detailed analyses and country-by-country summaries contained in the full study report are not included here. Should the reader desire more information on a given aspect of the analyses summarized here, the full report can be consulted. The reader may find, in many cases, that the references and data sources noted here provide a sufficient springboard for more extended, independent inquiries.

This summary and the full study report were prepared to serve two principal audiences: U.S. industry and federal government policy and decisionmakers. Heretofore there existed no detailed compilation of data and information on the potential international geothermal marketplace for use by either sector. U.S. industry needs such information if it is to take its unparalleled technical expertise and products to the overseas market. The federal government also needs this information if it is to effectively promote the export of U.S. geothermal products and services as mandated by the Renewable Energy Industry Development Act of 1983.

Neither the full study report nor this summary will provide either sector with a "master stroke" solution to its particular needs. This study does however, serve as a much needed first step in the process of increasing U.S. geothermal industry penetration of the international market. 


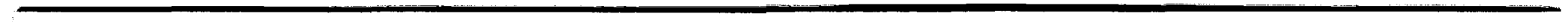




\section{TABLE OF CONTENTS}

Page

1.0 OVERVIEW.......................................... I

1.1 Introduction................................... 1

1.2 Value to the Reader.............................. 2

1.3 Study Approach.................................. 3

1.4 Study Results................................. 3

2.0 STATUS OF GEOTHERMAL DEVELOPMENT IN THE WORLD............. 4

2.1 Selection of Countries and Areas for Detailed Study...................................

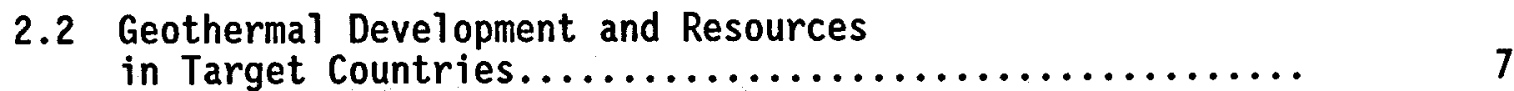

2.3 Economic and Energy Factors.................... 7

3.0 INTERNATIONAL POTENTIAL OF THE U.S. GEOTHERMAL INDUSTRY......

3.1 Characterization of the U.S. Geothermal Industry........ 10

3.2 Historic U.S. International Market Penetration......... 11

3.3 Future U.S. International Market Penetration........... 14

4.0 POTENTIAL MARKETS FOR U.S. GEOTHERMAL EXPORT DEVELOPMENT..... 14

5.0 FINANCIAL OPTIONS FOR U.S. GEOTHERMAL INDUSTRY

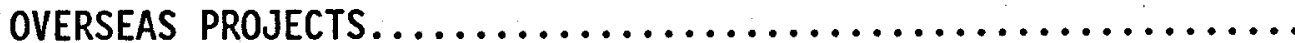

5.1 International Lending Agencies.................... 15

5.2 U.S. Government Assistance....................... 18

5.3 Geothermal Resources Council...................... 20 
6.0 CONCLUSIONS AND RECOMMENDATIONS........................ 20

6.1 Study Findings................................ 20

6.2 Study Recommendations.......................... 21

REFERENCES.......................................... 22

\section{LIST OF EXHIBITS}

2.1 Countries and Areas Selected for Detailed Consideration.......... 5

2.2 Worldwide Distribution of Geothermal Development Potential....... 6

2.3 Level of Development and Resource Quality for Countries and Geothermal Fields.............................. 8

2.4 Summary of Energy/Economic Indicators.................... 9

3.1 U.S. Industry Sectors Operating Within Each Leve1 of Geothermal Development.................................. 12

3.2 Historical Penetration of Geothermal Technology Exporters in the International Market....................... 13

4.1 Opportunities for U.S. Geothermal Industry by Leve1 of Work Required.

5.1 International Development and Funding Institutions............ 17

5.2 Federal Agency Export Assistance Program Summary.............. 19 


\section{ABSTRACT}

This report summarizes a study initiated to review and assess international developments in the geothermal energy field and to define business opportunities for the U.S. geothermal industry. The report establishes data bases on the status of worldwide geothermal development and the competitiveness of U.S. industry. Other factors identified include existing legislation, tax incentives, and government institutions or agencies and private sector organizations that promote geothermal exports.

Based on the initial search of 177 countries and geographic entities, 71 countries and areas were selected as the most likely targets for the expansion of the geothermal industry internationally. The study then determined to what extent their geothermal resource had been developed, what countries had aided or participated in this development, and what plans existed for future development. Data on the energy, economic, and financial situations were gathered.

Information has been selected and presented (1) to provide background data on the status of worldwide geothermal development and U.S. industry's involvement and (2) to serve as a reference source for the geothermal industry.

Summaries of the following are included herein:

- Past, present, and planned geothermal development in the 71 selected countries and areas.

o Involvement of U.S. and foreign geothermal industry in these countries.

- Energy, economic, and financial situations in these countries.

- International and U.S. agencies and organizations that either fund geathermal development projects or promote the export of U.S. goods and services.

General conclusions drawn pertaining to international geothermal activities and U.S. geothermal industry opportunities are:

1. Their potential for geothermal development in the world is much larger than is currently being exploited.

2. The U.S. geothermal industry is one of the leaders in geothermal development worldwide despite stiff competition from Japan, New Zealand, France, and I taly.

3. A five-point strategy is outlined to aid U.S. penetration of the international geothermal market. 


\section{REPORT SUMMARY}

\subsection{OVERVIEW}

\subsection{Introduction}

Recent fluctuations in oil prices and the present overabundance of electric energy have redirected the near-term and mid-term outlook for the U.S. geothermal industry from domestic to overseas markets. U.S. industry is thus faced with the challenge of translating its unparalleled expertise and technological superiority to the needs of a new marketplace. This is an imposing task for the geothermal industry, particularly when one considers that the bulk of the companies have grown up or evolved around the demands of a domestic market and have not had a great deal of exposure to the requirements of the international market. The opportunities are out there, however, as evidenced by size of the worldwide geothermal energy resource base and by the degree of interest and developmental activities at these resources. This document is intended not to serve as a master stroke for penetration of that market, but to help provide an indication of where the opportunities lie, and some of the basic information U.S. industry wi11 need to assess those opportunities on a case specific company-by-company basis.

This document is also intended to provide government policy and decisionmakers with information they need to aggressively pursue their mandate under the Renewable Energy Industries Act of 1983. This act provides the framework within which the Federal Government is to facilitate the promotion of U.S. renewable energy exports, including geothermal products and services. Under this act, the Committee on Renewable Energy Commerce and Trade (CORECT) was established to coordinate the activities of 14 federal agencies in pursuing this mandate. No compiled export statistics have existed for use by the Federal Government in assessing the export potential of U.S. geothermal energy products and services or the federal programs and policies which could be developed to enhance the export of those products and services. This study responds to that need by reviewing and assessing international developments in geothermal energy, highlighting potential export opportunities and outlining follow-on actions that the Federal Government can pursue in promoting the export of U.S. geothermal products and services.

The number of countries throughout the world exploring the use of geothermal resources has increased substantially over the past 15 years. The number of countries exploiting geothermal resources for power generation has increased from 2 to 10 within this period. This increase is primarily due to heightened emphasis on national energy security and corresponding increases in aid from industrialized countries and international funding organizations for developing indigenous energy resources in less developed countries. Just as international interest in geothermal energy has increased, so too have the capabilities of the U.S. geothermal industry. The U.S. leads the world in the development and use of geothermal energy with over 2000 MWe on-line. The industry that has supported that growth has superior expertise and capability to assist developing countries realize the benefits of the ir geothermal potential. 
This volume presents an expanded summary of the full report prepared in this study entitled "Review of International Geothermal Activities and Assessment of U.S. Industry Opportunities." Detailed discussions of the data collection and analyses, as well as descriptive data on the countries included in this study are presented in the full report and its appendices.

\subsection{Value to the Reader}

The primary function of this report is to present a comprehensive, consolidated international geothermal data base (developed from the best available published literature) and data analyses to: assist the Federal Government in establishing program plans and activities to promote geothermal export development; and to assist U.S. geothermal industry, its potential users, and financiers in understanding the status of current and future international markets, gaining an initial assessment of the energy, economic, and financial conditions of target market countries, and evaluating the global competitiveness of U.S. industry versus its international counterparts.

This study focuses on developing nations and industrialized countries/areas that have evidence of geothermal resources and are likely to require the assistance of foreign geothermal experts. Brief summaries of industrialized countries with established competitor geothermal industries (including USSR-aligned countries) and countries/areas with negligible geothermal potential are briefly included in the full report to assist the reader in understanding the global market. This report is not intended to represent a comprehensive market research analysis, which generally must be accomplished by the individual firm to address its specific interests.

While advances have been made in promoting export of U.S. geothermal equipment and services, certain needs must still be overcome for U.S. industry to successfully expand and continue international market penetration. This study is composed of four tasks that address, on a general level, some of these needs:

- Conduct a review of international geothermal development to identify areas with high geothermal potential.

- Assess the competitiveness of U.S. industry as indicated by its penetration in the international market and identify future market opportunities.

- Review federal and international funding agencies through which geothermal projects could be financed.

- Develop the framework for a strategy and recommendations for actions by the Federal Government to enhance geothermal export development. 


\subsection{Study Approach}

The study approach included:

- Identify those countries that have the greatest actual or potential geothermal resources, and that are likely to import the technology and services necessary to exploit these resources.

- Define the current level of geothermal development within the identified countries with respect to available U.S. goods and services.

- Assess, at a general level, the economic and energy market conditions within the identified countries that may impact a company's decision to pursue business development within that country.

- Identify the principal competitors and relative U.S. market share within the identified countries, based on historic data and future projections.

- Select target market countries based on a collective analysis of the resource, market, economic, energy and competitive data.

- Assess the access to financial sources to support or fund international geothermal development projects.

The supporting data is presented in the accompanying full report and is organized for the reader to easily focus on the industry sector or market country of their choice. Summarizations of that data and information are found here.

\subsection{Study Results}

Based on the results of the comprehensive literature search, data base development, and data analyses, the following conclusions were drawn:

- U.S. geothermal industry is a world leader in geothermal development as demonstrated by its past activities.

- Conducted exploration projects in at least 21 of the target countries.

- Supplied geothermal drilling equipment or services in at least six of the target countries.

- Participated in field development in at least 10 of the target countries.

- Participated in power plant design and construction in at least three of the target countries. 
The principle necessary ingredients exist for expanded and continued U.S. geothermal industry penetration into the international market, including technological superiority, strong potential market countries, and mechanisms for project financing.

- U.S. geothermal industry is technologically superior and has extensive experience and visibility in the international arena.

- Of 177 countries reviewed, 71 countries/areas exist with demonstrated or potential geothermal resources, and current or future needs for U.S. technology and expertise.

- Eight international funding organizations have been involved with geothermal projects, and four general funding mechanisms exist for accessing funds from these agencies.

0

A five-point strategy could be employed by the Federal Government to enhance the export development of U.S. geothermal technology through activities such as those undertaken by the Committee on Renewable Energy Commerce and Trade (CORECT).

- Measure U.S. industry interest in export development.

- Expand the international geothermal data base.

- Educate industry on international business development techniques and educate the market and financiers on geothermal energy.

- Expand efforts to disseminate information on international projects to U.S. industry.

- Improve access to funding for international projects.

\subsection{STATUS OF GEOTHERMAL DEVELOPMENT IN THE WORLD}

\subsection{Selection of Countries and Areas for Detailed Study}

A comprehensive literature search was conducted to determine the level of geothermal development in the international arena. As a result of this, 71 countries were identified that have evidence of geothermal resources and that are likely to require assistance and technology from foreign geothermal experts. In general, the study countries are not highly industrialized al though the level of geothermal development varies greatly from country to country. Exhibit 2.1 lists the study countries. This list includes Puerto Rico, Taiwan, the Azores, and Ascension Island which, although not countries, warrant separate consideration due to political or economic circumstances.

Exhibit 2.2 illustrates the worldwide distribution of geothermal development potential. Industrialized countries with established competitor geothermal industries and USSR-aligned countries were reviewed during this study but are not considered primary targets for U.S. geothermal industry. It 


\begin{tabular}{|c|c|}
\hline $\begin{array}{l}\text { Algeria } \\
\text { Argentina } \\
\text { Ascension Island } \\
\text { Azores } \\
\text { Bhutan } \\
\text { Bolivia } \\
\text { Brazil } \\
\text { Burma } \\
\text { Burundi } \\
\text { Cameroon } \\
\text { Cape Verde } \\
\text { Chad } \\
\text { Chile } \\
\text { China } \\
\text { Colombia } \\
\text { Costa Rica } \\
\text { Djibouti } \\
\text { Dominica } \\
\text { Dominican Republic } \\
\text { Ecuador } \\
\text { Egypt } \\
\text { El Salvador } \\
\text { Ethiopia } \\
\text { Fiji } \\
\text { Greece } \\
\text { Grenada } \\
\text { Guatemala } \\
\text { Haiti } \\
\text { Honduras } \\
\text { India } \\
\text { Indonesia } \\
\text { Jordan } \\
\text { Kenya } \\
\text { Korea, South } \\
\text { Madagascar } \\
\text { Malawi }\end{array}$ & $\begin{array}{l}\text { Malaysia } \\
\text { Mexico } \\
\text { Morocco } \\
\text { Mozambique } \\
\text { Nepal } \\
\text { Nicaragua } \\
\text { Nigeria } \\
\text { Panama } \\
\text { Papua New Guinea } \\
\text { Peru } \\
\text { Philippines } \\
\text { Puerto Rico } \\
\text { Rwanda } \\
\text { Saint Christopher and Nevis } \\
\text { Saint Lucia } \\
\text { Saint Vincent and the Grenadines } \\
\text { Samoa, Western } \\
\text { Saudi Arabia } \\
\text { Solomon Islands } \\
\text { Somalia } \\
\text { Sudan } \\
\text { Taiwan } \\
\text { Tanzania } \\
\text { Thailand } \\
\text { Tunisia } \\
\text { Turkey } \\
\text { Uganda } \\
\text { Vanuatu } \\
\text { Venezuela } \\
\text { Vietnam } \\
\text { Yemen, North } \\
\text { Yemen, South } \\
\text { Yugosiavia } \\
\text { Zaire } \\
\text { Zimbabwe }\end{array}$ \\
\hline
\end{tabular}

\section{Exhibit 2.1: Countries and Areas Selected for Detailed Consideration}




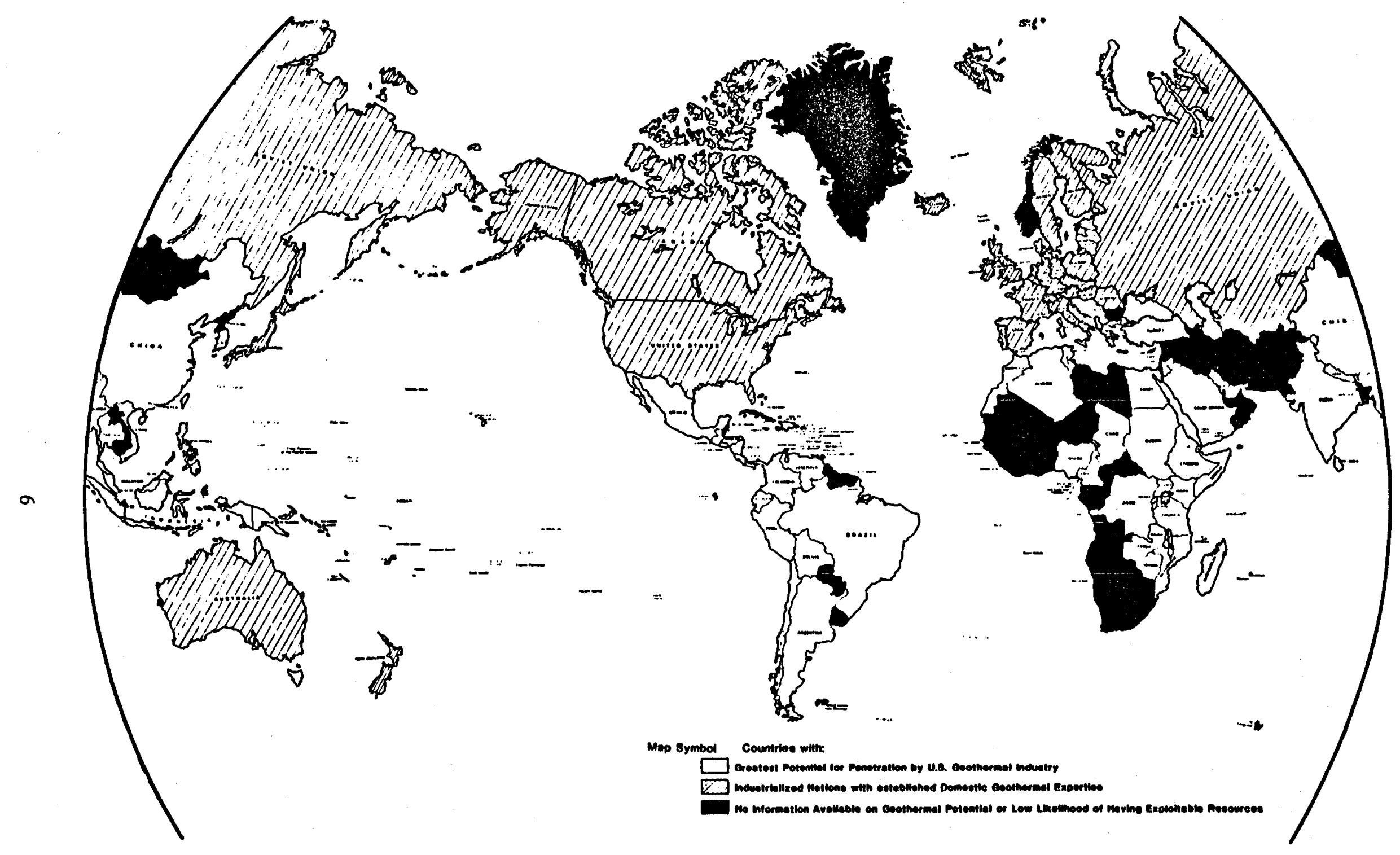

Exhibit 2.2: Worldwide Distribution of Geothermal Development Pofential 
is assumed the majority of geothermal work in these countries will 1ikely be performed by their own domestic industry. Historically, U.S. industry has had iimited penetration into these markets, and their respective market shares are not expected to increase significantly.

\subsection{Geothermal Development and Resources in Target Countries}

Exhibit 2.3 indicates the current level of development, estimated resource temperature, and existing geothermal electric capacity for each of the 71 countries included in the detailed study. As indicated, geothermal development within each country is characterized by a sequence of three levels and eight sublevels of geothermal development:

I. Exploration
a. Nationwide preliminary assessment
b. Site-specific reconnaissance
c. Detailed geophysical studies

II. Field Development

a. Exploratory drilling

b. Production drilling

III. Resource Utilization

a. Demonstration/research and development plant

b. Construction of commercial plant

c. Operation of commercial plant.

\subsection{Economic and Energy Factors}

All of the study countries have the potential for geothermal energy exploitation, however they vary significantly in economic and energy market conditions including: size; level and rate of economic development; overall economic health; need for new energy capacity; domestic energy resources; level of industrialization; and reliance on 011 imports. Data which can be used as indicators of the economic and energy conditions within the study countries were retrieved from available literature.

Exhibit 2.4 qualitatively summarizes seven statistical indicators to provide useful profiles of these countries. The qualitative values (high, medium, and low) assigned to each country for each indicator reflect the results of various equations which were applied to the raw data to develop ratios by which to rank the countries within each indicator. These ratios provide a measure of each country's need for geothermal energy and its economic strength to pay for that energy. Based on its rank compared to the other target countries, each country has been classified as:

o High - positive for possible geothermal development. (i.e., the country has either a need for new energy or a strong economy to support large, new projects) 


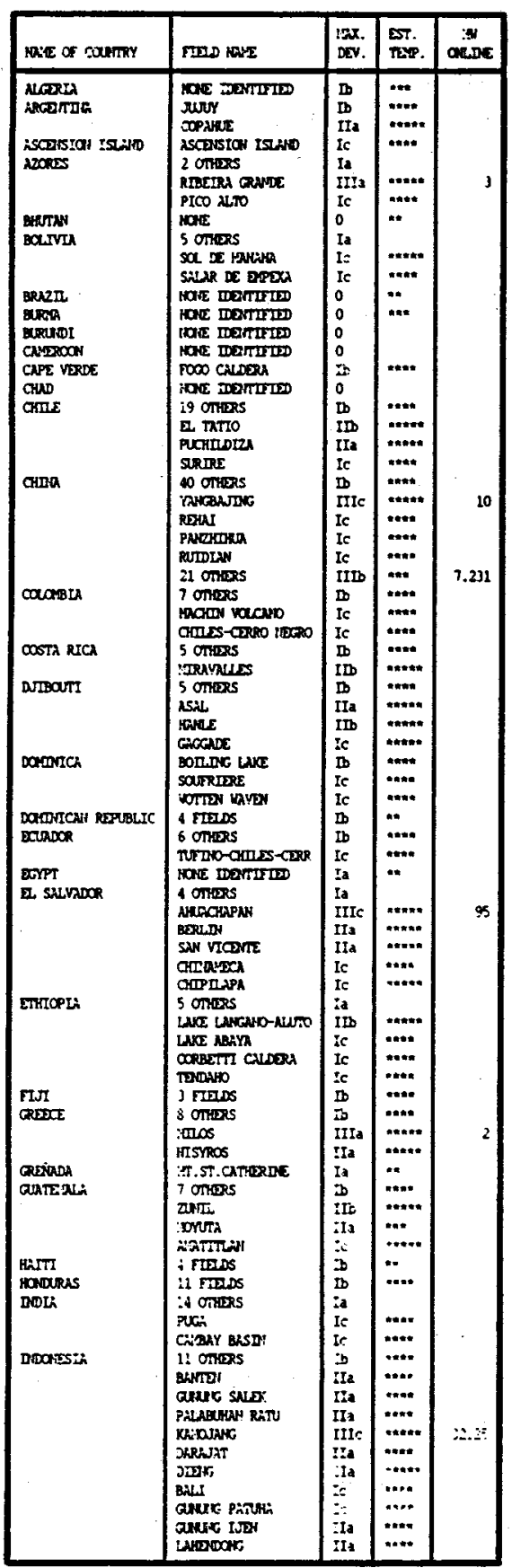

\begin{tabular}{|c|c|c|c|c|}
\hline $\operatorname{san} \alpha$ or country & FTo dove & ix. & $\begin{array}{l}\text { EST. } \\
\text { TEPP. }\end{array}$ & $\begin{array}{l}\text { is } \\
\text { aRLWE }\end{array}$ \\
\hline 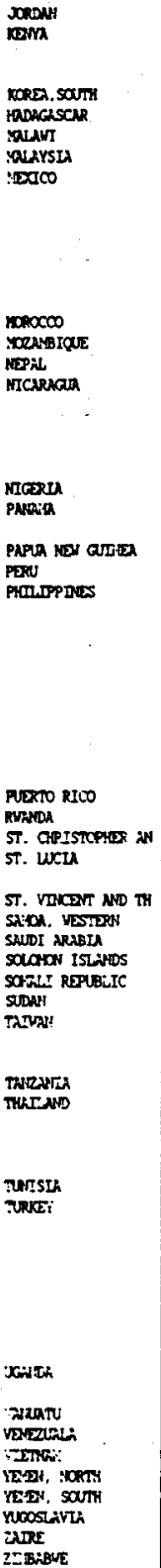 & 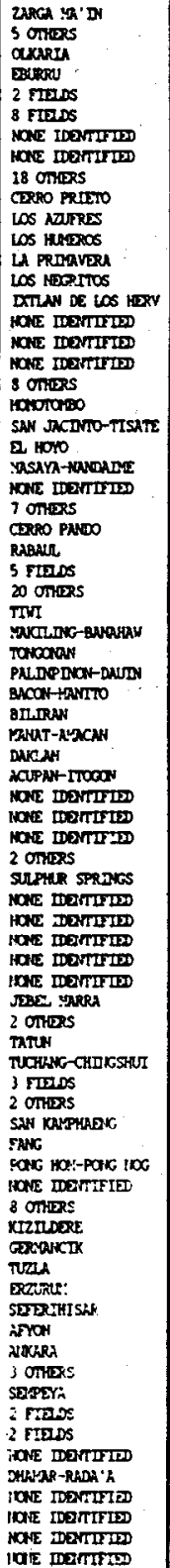 & 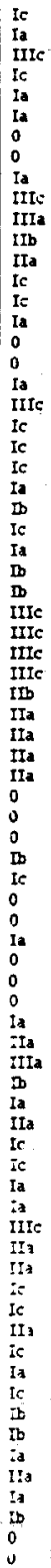 & 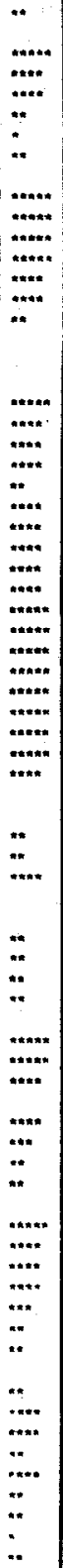 & $\begin{array}{r}330 \\
330 \\
153 \\
118.5\end{array}$ \\
\hline
\end{tabular}

KEY

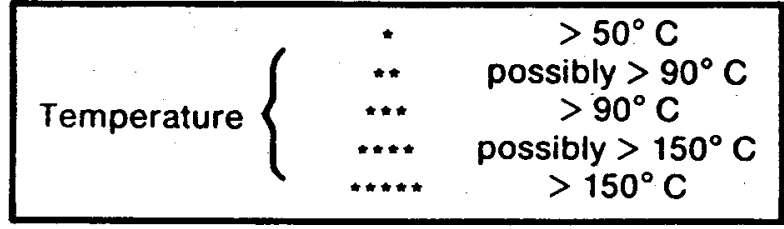

KEY

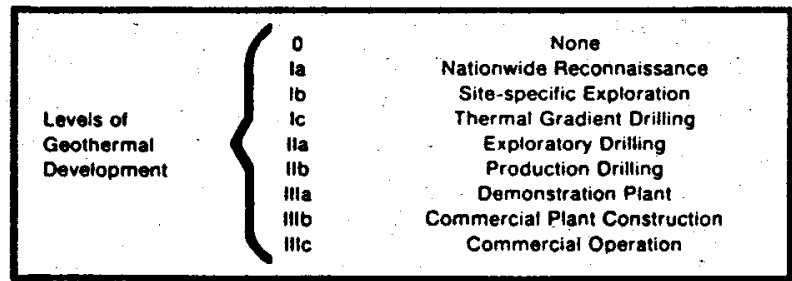

\section{Exhibit 2.3: Level of Development and Resource Quality for Countries and Geothermal Fields}




\begin{tabular}{|c|c|c|c|c|c|c|c|}
\hline 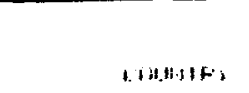 & $\begin{array}{l}\text { EIF } \\
\text { HET: CAA I TA }\end{array}$ & $\begin{array}{l}\text { IHNESTIENT } \\
\text { I:I IMAIE } \\
\text { FCTENTIAL }\end{array}$ & $\begin{array}{l}\text { I.EGFEE OF } \\
\text { ENEFFGY } \\
\text { DEPENDEHCE }\end{array}$ & $\begin{array}{l}\text { NEW ENERGY } \\
\text { RESERVES } \\
\text { NEEDS }\end{array}$ & $\begin{array}{l}\text { EXFOFTS AS } \\
\text { FFOFURTION } \\
\text { OF IMFOFTS }\end{array}$ & $\begin{array}{l}\text { INT' NATT IONAL } \\
\text { FESEFVES } \\
\text { GUVILAEILITY }\end{array}$ & $\begin{array}{l}\text { DEFT SEFVICE } \\
\text { AFILITY }\end{array}$ \\
\hline 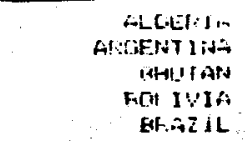 & $\begin{array}{l}\text { IIIHA } \\
\text { HISHA } \\
\text { HEDILM } \\
\text { HISH : }\end{array}$ & 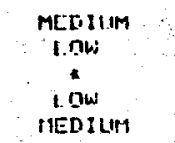 & $\begin{array}{l}\text { LOW } \\
\text { MEDIUM } \\
\text { MEDIUM } \\
\text { MEDIUM }\end{array}$ & $\begin{array}{l}\text { LOW } \\
\text { MEDIUM } \\
\text { LOW } \\
\text { MEDIUM }\end{array}$ & $\begin{array}{l}\text { MEDIUM } \\
\text { HIGH } \\
\text { * } \\
\text { HIGH } \\
\text { HIGH }\end{array}$ & $\begin{array}{l}\text { MEDIUM } \\
\text { HIGH } \\
* \\
\text { HIGH } \\
\text { LOW }\end{array}$ & $\begin{array}{l}\text { Low } \\
\text { LOW } \\
\text { Low } \\
\text { Low }\end{array}$ \\
\hline 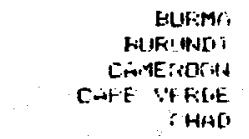 & $\begin{array}{l}\text { Le:W } \\
\text { Low } \\
\text { MELI]IM } \\
\text { Low } \\
\text { LOW }\end{array}$ & $\begin{array}{l}\text { HICH } \\
\text { HIint } \\
\text { MEDILM } \\
\\
\end{array}$ & $\begin{array}{l}\text { MEDIUM } \\
\text { HIGH } \\
\text { MEDIUM } \\
\text { HIGH } \\
\text { HIGH }\end{array}$ & $\begin{array}{l}\text { HIGH } \\
\text { LOW } \\
\text { MEDIUM } \\
\text { HIGH } \\
\text { HIGH }\end{array}$ & $\begin{array}{l}\text { HIGH } \\
\text { LOW } \\
\text { MEDIUM } \\
\text { LOW }\end{array}$ & $\begin{array}{l}\text { HIGH } \\
\text { LOW } \\
\text { LOW }\end{array}$ & $\begin{array}{l}\text { LOW } \\
\text { MEDIUM } \\
\text { HIGH }\end{array}$ \\
\hline $\begin{array}{r}\text { CHILE } \\
\text { CHINA } \\
\text { COLOMEIA } \\
\text { COSTA RICA } \\
\text { DIIEOUIII }\end{array}$ & $\begin{array}{l}\text { H]GHi } \\
\text { LOW } \\
\text { HIEH } \\
\text { HIGH } \\
\text { MEDIUM }\end{array}$ & $\begin{array}{l}\text { LOW } \\
\text { MELI: MI } \\
\text { MERjuM } \\
\text { LOW } \\
\star\end{array}$ & $\begin{array}{l}\text { MEDIUM } \\
\text { MEDIUM } \\
\text { MEDIUM } \\
\text { HIGH } \\
\text { HIGH }\end{array}$ & $\begin{array}{l}\text { LOW } \\
\text { MEDILM } \\
\text { MEDIUM } \\
\text { MEDIUM } \\
\text { HIGH }\end{array}$ & $\begin{array}{l}\text { HIGH } \\
\text { MEDIUM } \\
\text { LOW } \\
\text { MEDIUM } \\
\text { - }\end{array}$ & $\begin{array}{l}\text { HIGH } \\
\text { HIGH } \\
\text { HIGH } \\
\text { MEDIUM } \\
\end{array}$ & $\begin{array}{l}\text { MEDIUM } \\
\text { LOW } \\
\text { LOW } \\
*\end{array}$ \\
\hline $\begin{array}{r}\text { DOMINICA } \\
\text { DOMINJ CAIS REFUE } \\
\text { ECUADOF } \\
\text { EGVPT } \\
\text { EI. SALVAUOF }\end{array}$ & $\begin{array}{l}\text { LOW } \\
\text { HIGH } \\
\text { HIGH } \\
\text { MELILM } \\
\text { MEDIUM }\end{array}$ & $\begin{array}{l}\text { * } \\
\text { MEDIUM } \\
\text { MEDIUM } \\
\text { HIGH } \\
\text { LOW }\end{array}$ & $\begin{array}{l}\text { HIGH } \\
\text { HIGH } \\
\text { LOW } \\
\text { MEDILM } \\
\text { HIGH }\end{array}$ & $\begin{array}{l}\text { HIGH } \\
\text { HIGH } \\
\text { MEDIUM } \\
\text { HIGH } \\
\text { HIGH }\end{array}$ & $\begin{array}{l}\bullet \\
\text { LOW } \\
\text { HIEH } \\
\text { LOW } \\
\text { MEDIUM }\end{array}$ & $\begin{array}{l}\text { LOW } \\
\text { MEDIUM } \\
\text { LOW } \\
\text { MEDIUM }\end{array}$ & $\begin{array}{l}\text { LOW } \\
\text { LOW } \\
\text { LOW } \\
\text { HIGH }\end{array}$ \\
\hline $\begin{array}{r}\text { ETHICFIA } \\
\text { FIJI } \\
\text { GFEECE } \\
\text { GFENADA } \\
\text { GUATEMALA }\end{array}$ & $\begin{array}{l}\text { LOW } \\
\text { HIGH } \\
\text { HIGH } \\
\text { LOW } \\
\text { HIGH. }\end{array}$ & $\begin{array}{c}\text { MEDIUM } \\
\text { LOW } \\
\text { LOW }\end{array}$ & $\begin{array}{l}\text { HIGH } \\
\text { HIGH } \\
\text { MEDIUM } \\
\text { HIGH } \\
\text { MEDIUM }\end{array}$ & $\begin{array}{l}\text { LOW } \\
\text { HIGH } \\
\text { HIGH } \\
\text { HIGH } \\
\text { MEDIUM }\end{array}$ & $\begin{array}{c}\text { LOW } \\
\text { LOW } \\
\text { MEDIUM }\end{array}$ & $\begin{array}{l}\text { LOW } \\
\text { LOW } \\
\text { MEDIUM }\end{array}$ & $\begin{array}{l}\text { MEDIUM } \\
\text { MEDIUM } \\
\text { MEDIUM }\end{array}$ \\
\hline $\begin{array}{r}\text { HAITI } \\
\text { HONDURAS } \\
\text { INDIA } \\
\text { INDONESIA } \\
\text { JORDAN }\end{array}$ & $\begin{array}{l}\text { LOW } \\
\text { MEDIUM } \\
\text { LOW } \\
\text { MEDIUM } \\
\text { HIGH }\end{array}$ & $\begin{array}{l}\text { MEDIUN } \\
\text { LOW } \\
\text { MEDIUM } \\
\text { HIGH } \\
\text { HIGH }\end{array}$ & $\begin{array}{l}\text { HIGH } \\
\text { HIGH } \\
\text { MEDIUM } \\
\text { LOW } \\
\text { HIGH }\end{array}$ & $\begin{array}{l}\text { HIGH } \\
\text { MEDIUM } \\
\text { MEDIUM } \\
\text { MEDIUM } \\
\text { HIGH }\end{array}$ & $\begin{array}{l}\text { LOW } \\
\text { MEDIUM } \\
\text { LOW } \\
\text { MEDIUM } \\
\text { LOW }\end{array}$ & $\begin{array}{l}\text { LOW } \\
\text { LOW } \\
\text { HIGH } \\
\text { MEDIUM } \\
\text { MEDIUM }\end{array}$ & $\begin{array}{l}\text { HIGH } \\
\text { MEDILM } \\
\text { MEDIUM } \\
\text { MEDIUM } \\
\text { MEDIUM }\end{array}$ \\
\hline $\begin{array}{r}\text { KENYA } \\
\text { KOREA, SOUTH } \\
\text { MADAGASCAR } \\
\text { MALAWI } \\
\text { MALAYSIA }\end{array}$ & $\begin{array}{l}\text { LOW } \\
\text { HIGH } \\
\text { LOW } \\
\text { LOW } \\
\text { HYGH }\end{array}$ & $\begin{array}{l}\text { MEDIUM } \\
\text { MEDIUM } \\
\text { LOW } \\
\text { MEDIUM }\end{array}$ & $\begin{array}{l}\text { HIEH } \\
\text { HIGH } \\
\text { HIGH } \\
\text { HIGH } \\
\text { MEDIUM }\end{array}$ & $\begin{array}{l}\text { MEDIUM } \\
\text { HIGH } \\
\text { HIGH } \\
\text { MEDIUM } \\
\text { LOW }\end{array}$ & $\begin{array}{l}\text { LOW } \\
\text { MEDILM } \\
\text { MEDILM } \\
\text { LOW } \\
\text { MEDIUM }\end{array}$ & $\begin{array}{l}\text { MEDIUM } \\
\text { LOW } \\
\text { LOW } \\
\text { LOW } \\
\text { MEDIUM }\end{array}$ & $\begin{array}{l}\text { LOW } \\
\text { MEDIUM } \\
\text { LOW } \\
\text { HIGH }\end{array}$ \\
\hline $\begin{array}{r}\text { MEXICO } \\
\text { MORDCCO } \\
\text { MOZAMBIQUE } \\
\text { NEPAL } \\
\text { NICAFAEUA }\end{array}$ & $\begin{array}{l}\text { HIGH } \\
\text { MEDIUM } \\
\text { LOW } \\
\text { LOW } \\
\text { MEDIUM }\end{array}$ & $\begin{array}{l}\text { MEDIUM } \\
\text { MEDIUM } \\
* \\
\text { LOW }\end{array}$ & $\begin{array}{l}\text { MEDIUM } \\
\text { HIGH } \\
\text { MEDIUM } \\
\text { HIGH } \\
\text { HIEH }\end{array}$ & $\begin{array}{l}\text { MEDIUM } \\
\text { HIGH } \\
\text { LOW } \\
\text { LOW } \\
\text { MEDIUM }\end{array}$ & $\begin{array}{l}\text { HIGH } \\
\text { LOW } \\
\text { LOW } \\
\text { LOW } \\
\text { LOW }\end{array}$ & $\begin{array}{l}\text { MEDIUM } \\
\text { LOW } \\
\text { MEDIUM } \\
\text { LOW }\end{array}$ & $\begin{array}{l}\text { LOW } \\
\text { LOW } \\
\text { HIGH } \\
\text { MEDIUM }\end{array}$ \\
\hline $\begin{array}{r}\text { NIGERIA } \\
\text { PANAMA } \\
\text { PAFUA NEW GUINE } \\
\text { PERU } \\
\text { FHILIFFINES }\end{array}$ & $\begin{array}{l}\text { MEDIUM } \\
\text { HIGH } \\
\text { MEDIUM } \\
\text { MEDIUM } \\
\text { MEDIUM }\end{array}$ & $\begin{array}{l}\text { MEDIUM } \\
\text { MEDIUM } \\
\text { LOW } \\
\text { MEDIUM }\end{array}$ & $\begin{array}{l}\text { LOW } \\
\text { HIEH } \\
\text { HIGH } \\
\text { MEDILM } \\
\text { HIGH }\end{array}$ & $\begin{array}{l}\text { LOW } \\
\text { HIGH } \\
\text { LOW } \\
\text { MEDIUM } \\
\text { HIGH }\end{array}$ & $\begin{array}{l}\text { MEDIUM } \\
\text { LOW } \\
\text { MEDIUM } \\
\text { MEDIUM } \\
\text { LOW }\end{array}$ & $\begin{array}{l}\text { LOW } \\
\text { LOW } \\
\text { MEDIUM } \\
\text { HIGH } \\
\text { LOW }\end{array}$ & $\begin{array}{l}\text { MEDIUM } \\
\text { HIGH } \\
\text { MEDIUM } \\
\text { MEDIUM } \\
\text { MEDIUM }\end{array}$ \\
\hline $\begin{array}{r}\text { FWANDA } \\
\text { ST. KITTS } \\
\text { ST. LUCIA } \\
\text { ST. LINCENT/GRE } \\
\text { SAMOA }\end{array}$ & $\begin{array}{l}\text { LOW } \\
\text { MEDIUM } \\
\text { MEDIUM } \\
\text { MEDIUM }\end{array}$ & $\div$ & $\begin{array}{r}\text { HIGH } \\
\text { HIGH } \\
\text { HIGH } \\
\text { HIGH }\end{array}$ & $\begin{array}{l}\text { MEDIUM } \\
\text { HIGH } \\
\text { HIGH } \\
\text { HIGH }\end{array}$ & $\begin{array}{c}\text { LOW } \\
* \\
*\end{array}$ & $\begin{array}{c}\text { MEDIUM } \\
* \\
* \\
*\end{array}$ & $\begin{array}{c}\text { HIGH } \\
\vdots \\
* \\
*\end{array}$ \\
\hline $\begin{array}{r}\text { SAUDI AFAEIA } \\
\text { SOLOMON ISLANDS } \\
\text { SOMALIA } \\
\text { BUDAN } \\
\text { TAIWAN }\end{array}$ & $\begin{array}{l}\text { HIGH } \\
\text { MEDIUM } \\
\text { LOW } \\
\text { LOW } \\
\square\end{array}$ & $\begin{array}{l}\text { HIGH } \\
\text { LOW } \\
\text { MEDIUM }\end{array}$ & $\begin{array}{l}\text { LOW } \\
\text { HIGH } \\
\text { HIGH } \\
\text { HIGH } \\
\leftarrow\end{array}$ & $\begin{array}{l}\text { LOW } \\
\text { HIGW } \\
\text { HIGH } \\
\text { MEDIUM }\end{array}$ & $\begin{array}{c}\text { HIGH } \\
\text { LOW } \\
\text { LOW } \\
*\end{array}$ & $\begin{array}{l}\text { HIGH } \\
\text { LOW } \\
\text { LOW } \\
\therefore \text { \% }\end{array}$ & $\begin{array}{l}* \\
\text { MEDIUM } \\
\text { MEDIUM } \\
*\end{array}$ \\
\hline $\begin{array}{l}\text { TANZAINIA } \\
\text { THAILAND } \\
\text { TUNISIA } \\
\text { TUFIEY } \\
\text { UGANDA }\end{array}$ & $\begin{array}{l}\text { LOW } \\
\text { MEDIUM } \\
\text { HIEH } \\
\text { HIGH } \\
\text { LOW }\end{array}$ & $\begin{array}{l}\text { MEDIUM } \\
\text { MEDIUM } \\
\text { MEDIUM } \\
\text { MEDIUM } \\
\text { LOW }\end{array}$ & $\begin{array}{l}\text { MIGH } \\
\text { HIGH } \\
\text { LOW } \\
\text { MEDIUM } \\
\text { HIGH }\end{array}$ & $\begin{array}{l}\text { LOW } \\
\text { HIGM } \\
\text { MEDIUM } \\
\text { MEDIUM } \\
\text { MEDIUM }\end{array}$ & $\begin{array}{l}\text { Low } \\
\text { LOW } \\
\text { Low } \\
\text { LOW } \\
\text { MED IUM. }\end{array}$ & $\begin{array}{l}\text { Low } \\
\text { LOW } \\
\text { LOW } \\
\text { MEDIUM }\end{array}$ & $\begin{array}{l}\text { MEDIUM } \\
\text { LOW } \\
\text { LOW } \\
\text { * }\end{array}$ \\
\hline $\begin{array}{r}\text { VANUATU } \\
\text { VENEZUELA } \\
\text { VIETNAM } \\
\text { VEMEN, NORTH } \\
\text { YEMEN, SOUTH }\end{array}$ & $\begin{array}{l}* \\
\text { LOW } \\
\text { LOW }\end{array}$ & $\begin{array}{l}\text { MEDIUM } \\
\text { HIGH } \\
\text { HIT }\end{array}$ & $\begin{array}{l}\text { LOW } \\
* \\
\text { HIGH }\end{array}$ & $\begin{array}{l}\text { MEDrum } \\
\text { MEDIUM }\end{array}$ & $\begin{array}{l}\text { HIGH } \\
\text { Low } \\
\text { LOW }\end{array}$ & $\begin{array}{l}\text { HIGH } \\
\text { LOW } \\
\text { LOW }\end{array}$ & $\begin{array}{l}\text { MEDIUM } \\
\text { MEDIUM } \\
\text { LOW }\end{array}$ \\
\hline $\begin{array}{r}\text { YUGOSLAVIA } \\
\text { ZAIRE } \\
\text { ZIMEAEWE }\end{array}$ & $\begin{array}{l}\text { HIGH } \\
\text { LOW } \\
\text { MEDIUM }\end{array}$ & $\begin{array}{l}\text { MED IUM } \\
\text { MEDI UM } \\
\text { LOW }\end{array}$ & $\begin{array}{l}\text { MEDIUM } \\
\text { MEDIUM } \\
\text { MEDIUM }\end{array}$ & $\begin{array}{l}\text { MEDIUM } \\
\text { LOW } \\
\text { LOW }\end{array}$ & $\begin{array}{l}\text { MEDIUM } \\
\text { HIGH } \\
\text { MEDIUM }\end{array}$ & $\begin{array}{l}\text { Low } \\
\text { Low } \\
\text { LOW }\end{array}$ & $\begin{array}{l}\text { HIGH } \\
\text { LOW }\end{array}$ \\
\hline
\end{tabular}


- Medium - moderate likelihood of geothermal development.

- Low - negative outlook for geothermal development (for that indicator).

Extreme care should be taken in interpreting these data -- statistical methods, coverage, and definitions may vary significantly from country to country.

Higher values of "Gross Domestic Product (GDP) Per Capita" and "Investment Climate Potential" indicate strong, growing economies that may need additional energy production to support them. A high value of "Exports as Proportion of Imports" indicates a healthy economy and an ability to increase imports for new capital projects. The "International Reserves Availability" indicates the availability of foreign exchange cash to cover imports or to finance new projects. "Debt Service Ability" indicates the ability of the country to take on new debt, as would be required to finance new projects.

While these indicators do not give the complete picture, they do provide an objective basis to estimate the climate for geothermal development in a particular country. However, these statistics do not reflect other factors such as the quality of the geothermal resource or political factors that may significantly impact the likelihood of geothermal development.

\subsection{INTERNATIONAL POTENTIAL OF THE U.S. GEOTHERMAL INDUSTRY}

\subsection{Characterization of the U.S. Geothermal Industry}

The U.S. is by far the world leader in geothermal development. As of 1986, its on-line geothermal electric generating capacity was over 2,000 MWe, representing 42 percent of the world's total on-line geothermal electricity. This is 2.26 times the capacity of the Philippines, the world's second largest producer (DiPippo, 1986). In addition, U.S. geothermal experience extends beyond electric generation to include some 253 direct-use, on-line projects with estimated usage of approximately 1,625 billion Btu/year (Kenkeremath and others, 1985).

The U.S. geothermal industry has evolved into a non-homogenous entity of small and large, specialized and integrated, national and international firms. The industry can be characterized into the following seven sectors or categories:

- Exploration - conduct all phases of exploration prior to deep exploratory drilling.

- 0ilfield Service/Supply - provide services for drilling deep exploratory and production wells.

- Engineering/Consulting Services - drilling, production, and reservoir engineering/consultants required throughout all aspects of development. 

produced to a utility or power plant.

Project Design and Construction Management - design and/or build end-use facilities for electric production or direct use.

- Turbo-Generator Manufacturers - supply turbine or turbine generator sets.

- 0ther Component/Manufacturers/Suppliers - supplies generic materials (valves, pipes, controls, etc.).

Exhibit 3.1 illustrates the various sectors of industry operating within the levels of geothermal development as previously defined.

\subsection{Historic U.S. International Market Penetration}

To characterize the competitiveness of U.S. geothermal industry in the foreign market, available information and literature were reviewed describing international projects and the supplier source countries. These results are presented in Exhibit 3.2 as the total activities of the primary exporting countries (U.S., Japan, France, New Zealand, and Italy) within each of the 71 study countries. The matrix also includes a column labeled "Other" to account for any significant contribution by companies from other than the five major exporters, and a column labeled "Domestic" to account for work performed by companies based within the importing country. While these data are approximated from the best available literature sources, they are believed to be sufficiently accurate and complete to provide an approximate profile of the activities of various countries in the international geothermal market.

Based on these data, the historic market penetration of the major geothermal exporters can be ranked within each industry sector:

Exploration: The U.S. has a commanding lead ( 21 countries), followed by Italy (14), and then France, Japan, and New Zealand, $(9,7$, and 6, respectively). Several other countries have performed international work in this sector, although to an overall lesser extent.

0ilfield Service/Supply: The U.S. once again has the lead (7), undoubtedly due to the ubiquitousness of the U.S. oil industry. However, the other countries also have some representation in this sector. France has performed work in 3 countries; New Zealand, 3; and Italy, 2. Other countries that have performed work in this sector include Great Britain and Hungary.

Engineering/Consulting Services: Italy and New Zealand, with work performed in 10 and 9 countries respectively, have the lead in this category, primarily owing to the government-owned Italian companies and Geothermal Energy of New Zealand (GENZL). U.S. (6) follows, with France and Japan at the bottom. 


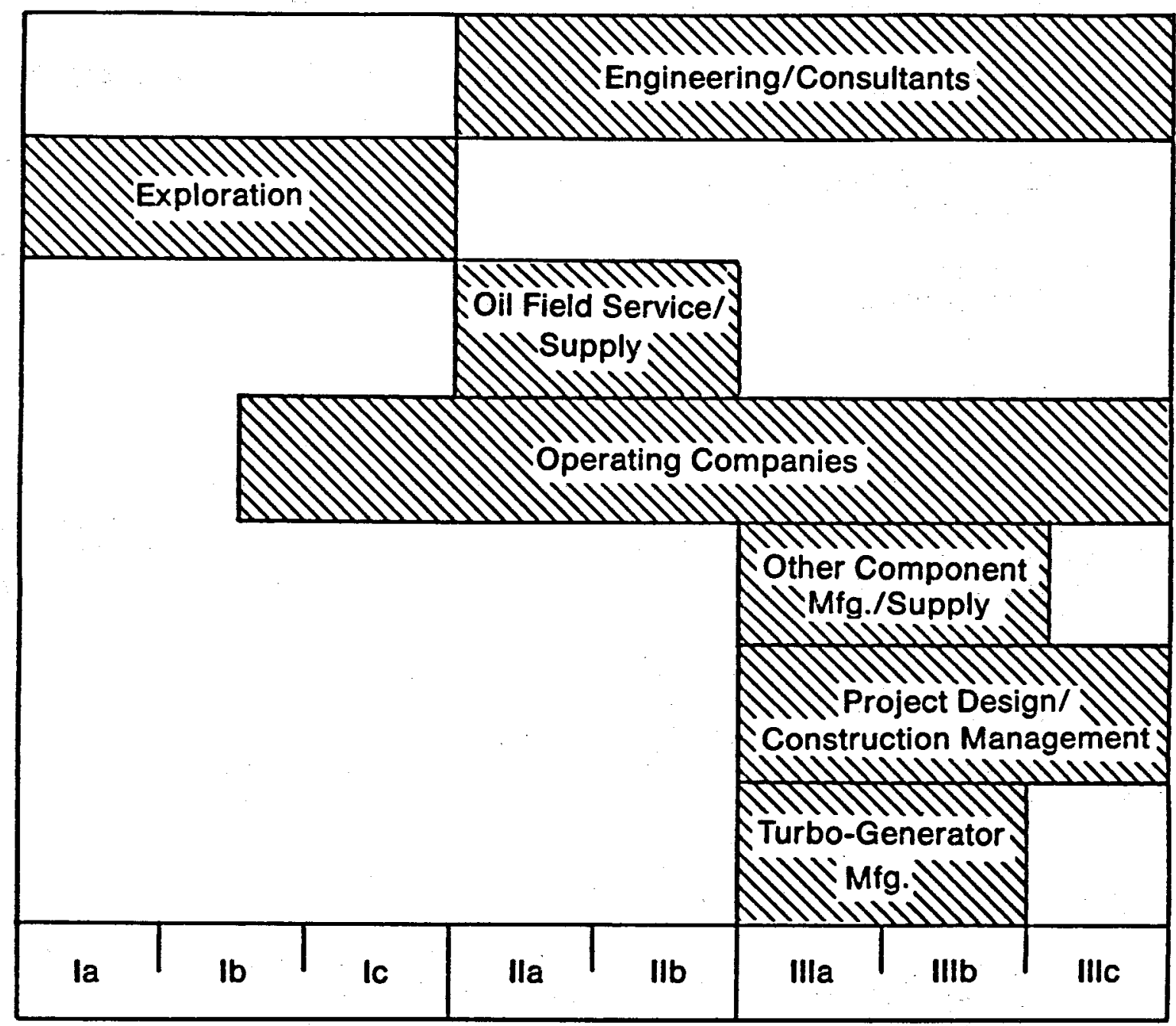

\section{EXPLORATION II. FIELD
DEVELOPMENT \\ III. RESOURCE UTILIZATION}

Exhibit 3.1: U.S. Industry Sectors Operating within Each Level of Geothermal Development 


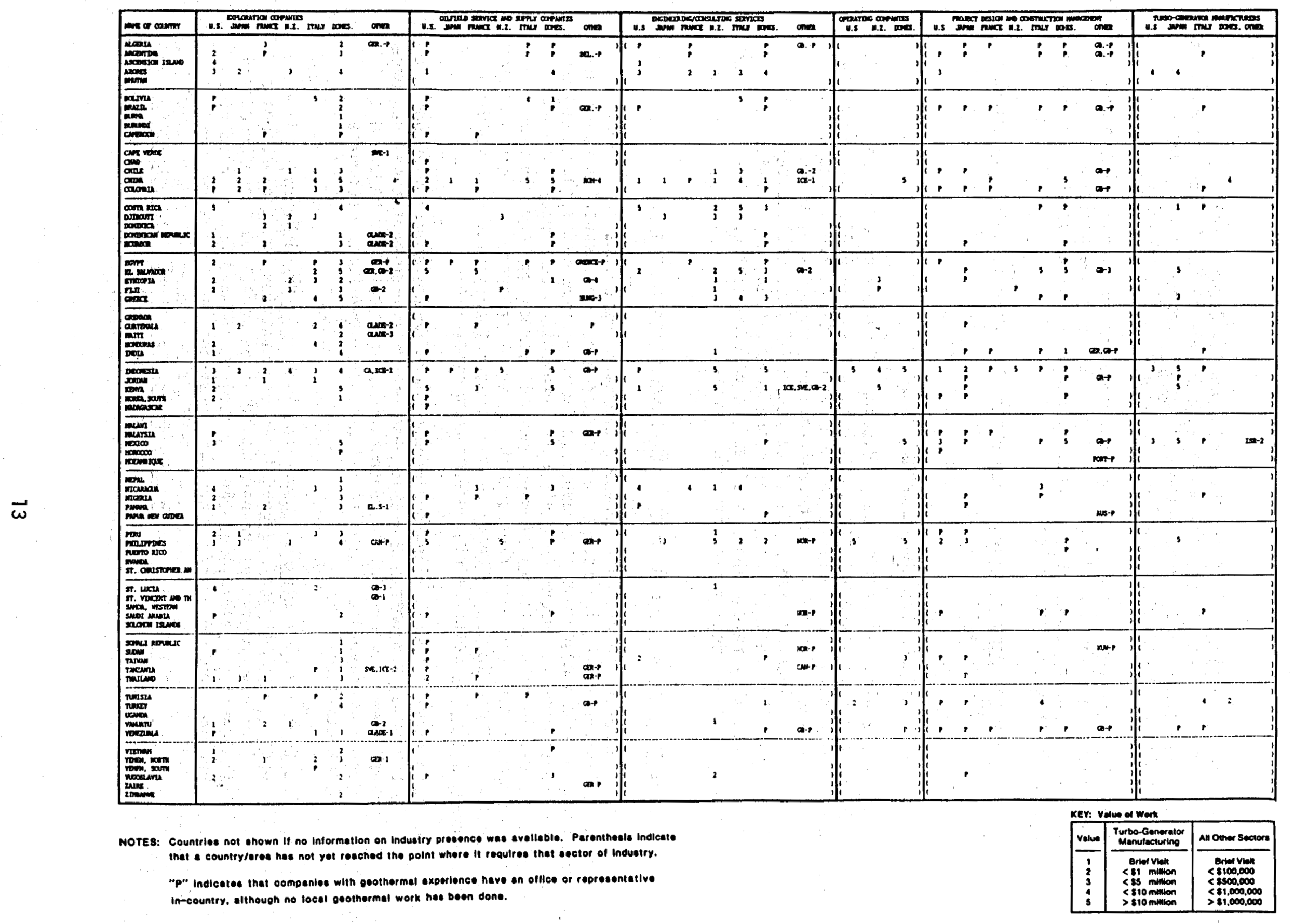

\section{Exhibit 3.2: Historical Penetration of Geothermal Technology Exporters in the International Market}


Operating Companies: Only the U.S. (3) and New Zeal and (4) are represented. The U.S. company being Unocal and the New Zealand company is once again GENZL. Both Unocal and GENZL are companies that combine exploration and engineering/consulting on particular projects.

Project Design/Construction Management: The information available does not present a clear superiority for any of the major exporters of geothermal energy technology. It does, however, point out that France is absent in this particular sector.

Turbo-Generator Manufacturers: Japan has the clear lead (8), followed by the U.S. (3) and Italy (1).

\subsection{Future U.S. International Market Penetration}

Exhibit 3.2 also allows limited prediction of future competition for U.S. industry in countries where geothermal work is not yet in progress. A "P" has been used to indicate the "presence" of competitors by the locations where offices and/or subsidiaries of geothermal-related companies of various nationalities are located within the 71 target countries. Collectively, the data in Exhibit 3.2 are useful in gauging the competition in a particular country, because they reveal who has already conducted geothermal projects and what nations are well positioned for future work.

\subsection{POTENTIAL MARKETS FOR U.S. GEOTHERMAL EXPORT DEVELOPMENT}

Companies attempting to market their geothermal products or expertise abroad will primarily be interested in areas, regions, or countries where the level of geothermal development is appropriate for the services they can best provide. Based on data previously discussed, the study countries have been aggregated within five categories of geothermal technology requirements to identify target countries and fields that may be of interest to a given company (Exhibit 4.1). The following categories represent the type of work required for the next step of development for each country or field:

Category 1 - Countries Requiring Nationwide Assessments includes countries/regions that are in need of nationwide geothermal resource assessments. None of the countries in this category have had a comprehensive study directed at assessing geothermal resource potential.

- Category 2 - Countries and Regions Requiring Prel iminary Geologic/Geophysical Surveys includes countries and regions where relatively comprehensive nationwide assessments have been conducted to identify potential geothermal fields, and are now in need of preliminary geologic/geophysical surveys.

Category 3 - Fields Possibly Ready for Deep Exploratory Drilling includes fields that have undergone shallow thermal gradient drilling and are now ready for deep exploratory drilling. 

includes fields containing at least one deep exploratory well and for which production drilling is next required to further delineate or develop the field.

- Category 5 - Proven Fields Undergoing Production Drilling, Plant Construction or Operation includes countries in which the existence and viability of the geothermal field has already been established. Most of these fields are ready for power plant construction or have existing plants planned for expansion.

The matrix in Exhibit 4.1 summarizes the opportunities for U.S. geothermal industry within each country by the category of technology required. Charts are presented in the full report that summarize the resource data, information on geothermal competitor countries, and energy and economic information for each country within the five categories. Countries with more than one geothermal field may appear in more than one category.

\subsection{FINANCIAL OPTIONS FOR U.S. GEOTHERMAL INDUSTRY OVERSEAS PROJECTS}

The World Bank estimates that, over the next 10 years, $\$ 130$ billion in investment will be needed annually to meet the projected energy demand in developing countries, and half of that total will come from international sources (World Bank, 1983). Several international and federal organizations administer export financing and assistance services which can be of use to the U.S. geothermal industry.

\subsection{International Lending Agencies}

International development organizations offer a variety of assistance programs including: financing; insuring investments; identifying target markets; 1ocating business opportunities, including joint venture partners; conducting feasibility studies and trade analyses; and in-country training and assistance. Loans or grants from these institutions are usually issued directly to the host country government; hence, U.S. goods and services are generaliy procured directly by the host country agency. Exhibit 5.1 summarizes the services available from each of the international funding institutions. The international organizations that have been involved in geothermal projects include:

- United Nations Development Programme - has funded 39 geothermal resource-related projects around the world, including Ethiopia, China, Kenya, Bolivia, and Honduras.

- World Bank - has financed at least 18 geothermal projects involving exploration, resource development and power plant construction in several countries including Mexico, El Salvador, Kenya, Indonesia, Philippines, Yemen Arab Republic, and Djibouti.

- Inter-American Development Bank - has co-financed reconnaissance, prefeasibility, feasibility, exploratory, and development projects in Nicaragua, Guatemala, and Costa Rica. 


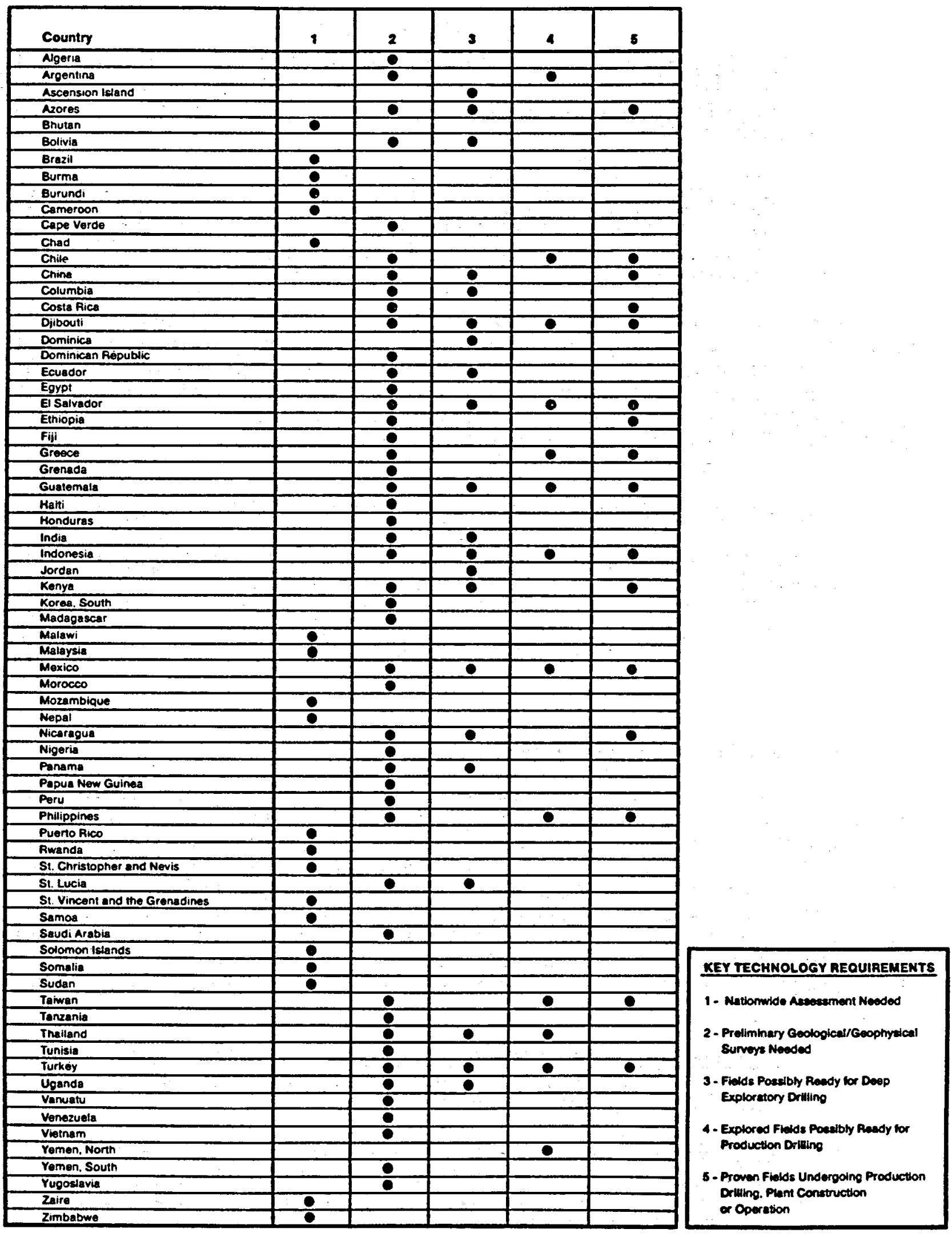

EXhibit 4.1: OPPORTUNITIES FOR U.S. GEOTHERMAL INDUSTRY BY LEVEL OF WORK REQUIRED 


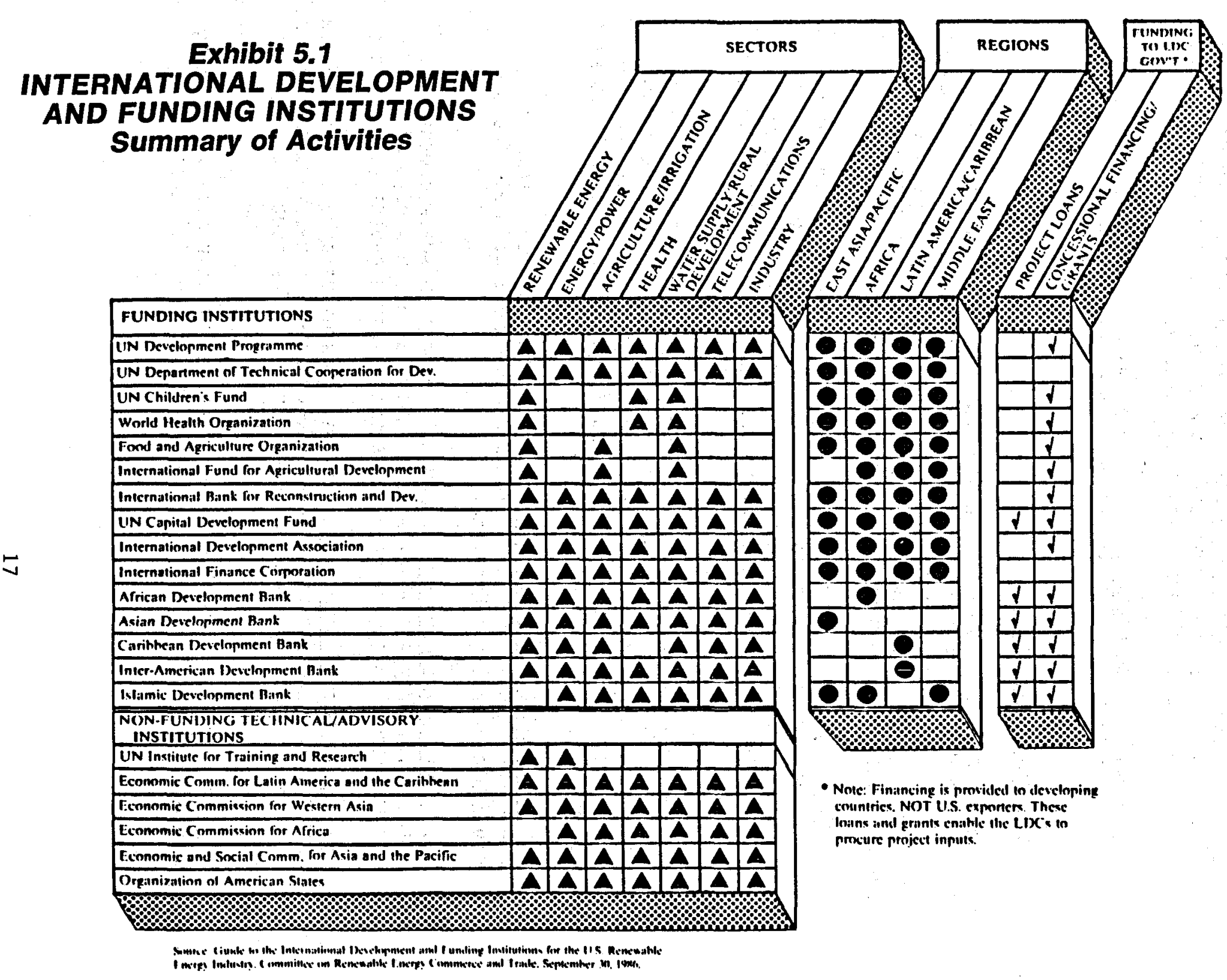


- Asian Development Bank - has provided technical assistance for feasibility studies in Indonesia and a geothermal steam pricing policy study in the Philippines.

- African Development Bank - has allocated $\$ 2.2$ million (1984) for a successful \$16.6 million geothermal exploration project in Djibouti.

- European Economic Community - has co-financed prefeasibility, installation, and expanded field development projects in Ethiopia, Ecuador, St. Lucia Island, Kenya, and Greece.

- Caribbean Development Bank - has provided recommendations on the development of a geothermal field on St. Lucia Island.

\subsection{U.S. Government Assistance}

Exhibit 5.2 summarizes the export assistance and financial services available from the U.S. Government. Each agency indicated offers programs that may be of use to the geothermal industry. Many of these agencies have been involved in various renewable energy projects. The following agencies have experience particularly relevant to geothermal energy:

- U,S. Agency for International Development - has been involved in airborne geothermal exploration in Jordan, and geothermal project evaluation in the Philippines; also provides foreign exchange to developing countries with which to purchase products and development services.

- Export-Import Bank - with no specific geothermal experience, the Export-Import Bank has programs and services for the energy industry that may be appropriate for geothermal projects, and acts on behalf of the U.S. to counter unfair trade arrangements offered by competing countries.

- Trade and Development Program - finances feasibility studies and development projects that eventually lead to exportation of U.S. goods to developing countries.

- U.S. Department of Energy - conducts research and development of geothermal energy technologies and participates in several International Energy Agency agreements regarding geothermal projects.

- U.S. Department of Commerce - provides numerous export assistance and market development services including trade missions, market research studies, product information dissemination, and export development seminars.

- U.S Department of Interior - provides relevant information regarding energy development projects in the seven U.S. territories. 


\section{Exhibit 5.2}

\section{FEDERAL AGENCY EXPORT ASSISTANCE}

PROGRAM SUMMARY

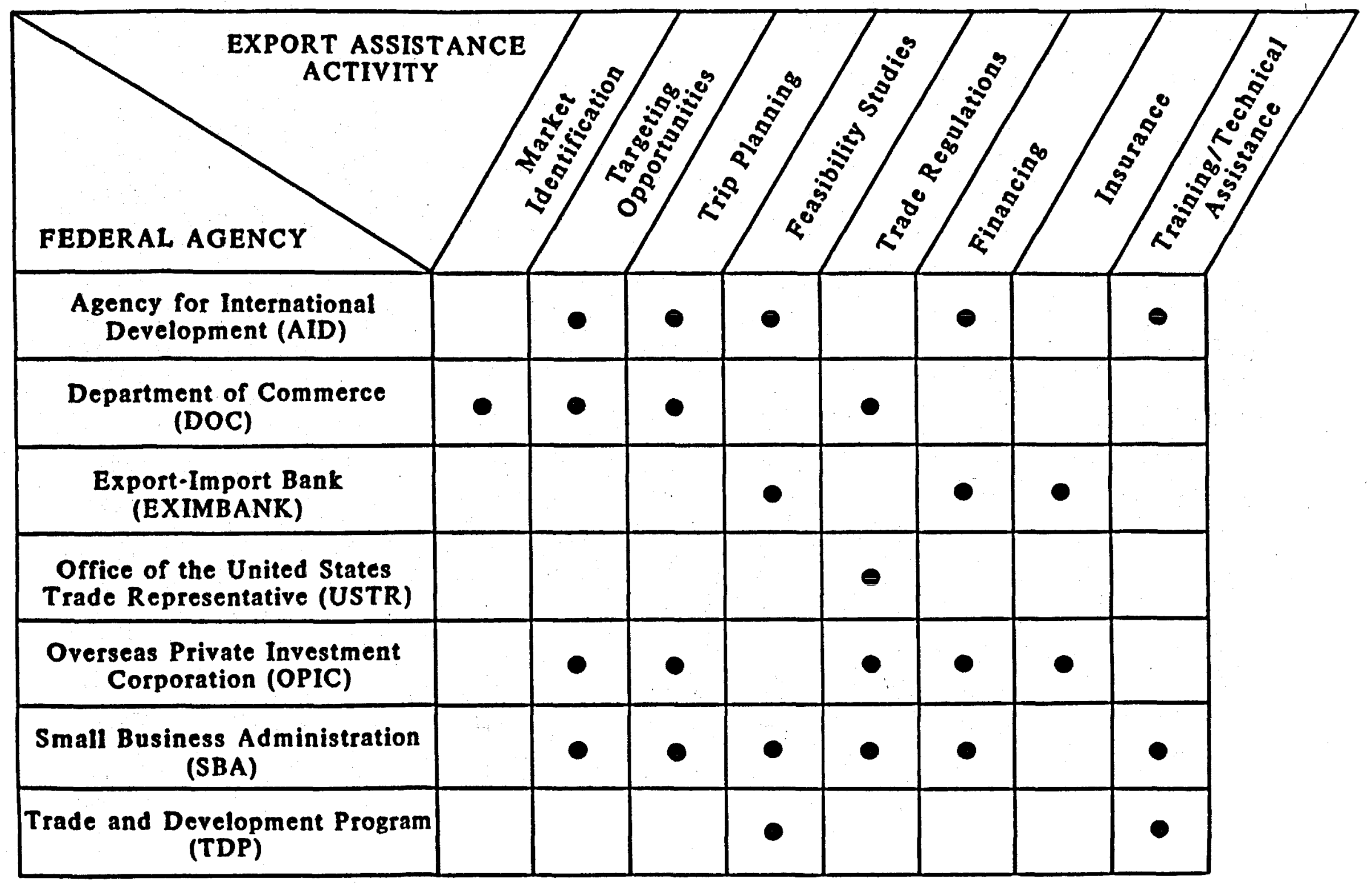



abroad by conducting interagency activities including educating decision-makers and end-users on the technologies, educating industry on available services, analyses of export barriers such as financing, and funding trade shows.

\subsection{Geothermal Resources Council}

The Geothermal Resources Council (GRC) is the only internal private sector organization that exclusively promotes the geothermal industry. GRC offers conferences, workshops, courses, and educational materials as well as providing a forum for the U.S. geothermal industry. Current membership is approximately 1300 individual and 80 corporate members.

\subsection{CONCLUSIONS AND RECOMMENDATIONS}

\subsection{Study Findings}

In summary, this study revealed that the three necessary ingredients for successful U.S. geothermal industry penetration into the international market are already present:

- U.S. Technological Superiority - U.S. industry has extensive experience and involvement in the international geothermal market and possesses unquestionable and superior qual ifications to perform all aspects of geothermal exploration and development.

- Available Market - 71 countries and areas were identified with demonstrated or likely geothermal resources and probable needs for U.S. technology and expertise, and represent the primary international markets for U.S. industry demonstrating an extensive available growth market.

- Project Financing - Numerous federal and international export financing and assistance programs exist to assist U.S. industry; eight international funding organizations have had direct experierice financing geothermal-related projects.

The study results clearly indicate that the U.S. geothermal industry is unmistakably a world leader among the exporting countries as indicated by its prominence in historic markets. Even in the face of serious competition from the industrialized geothermal nations, the overall overseas market penetration statistics for U.S. industry are impressive. However, the majority of this international presence primarily involves a small group of U.S. companies. There is undoubtedly a large sector of the U.S. industry that could be but currently is not significantly involved with international geothermal activities. 
The target market countries identified in this study include:

- 20 countries requiring nationwide resource assessments

$0 \quad 47$ countries with fields awaiting detailed geophysical analysis

- 28 fields ready for field development

- 11 countries with geothermal power on-line, and another 5 in the process of plant construction or production drilling.

U.S. industry can encounter international project financing through four mechanisms:

- Internationally Funded Projects - financed by international lending or funding organizations

- Foreign Aid Funded Projects - foreign aid grants to a specific country

- Domestically Funded Projects - host country governments where the project is located

- Private Funding Sources - private funding for money-making ventures.

\subsection{Study Recommendations}

Based on the results of this study, a recommended strategy has been developed for the Federal Government to promote expanded and continued U.S. penetration of the international geothermal market. The five components of this strategy are:

1 - Measure U.S. industry interest in geothermal export development

2 - Expand the international geothermal resource and market data base initiated in this study

3 - Educate U.S. industry on export development techniques and educate host country governments and financial institutions regarding the commercial status of geothermal energy

4 - Disseminate information on international projects to U.S. industry

5 - Improve access to financing for international projects.

Many of these aspects are currently being addressed by CORECT on behalf of the renewable energy industry in genera7. To the extent possible, the geothermal community should utilize these CORECT activities to gain their maximum benefit for U.S. geothermal energy export development. 


\section{REFERENCES}

DiPippo, R., (1986), "Geothermal Power Plants, Worldwide Status - 1986," Proceedings: Tenth Annual Geothermal Conference and Workshop, Electric Power Research Institute, AP-5059-SR, P. 2-3 to 2-18.

Kenkeremath, D., Blackett, R., Satrape, J., and Beeland, G., (1985), "The Current Status of Geothermal Direct Use Development in the United States," 1985 International Symposium on Geothermal Energy, International Volume, Geothermal Resources Council, pp. 223-236.

References used in compiling geothermal development information on particular countries are included with each country description in Appendices $A$ and $B$ of the full report.

Sources of statistical data on energy, economics, and finance are included with the detailed data in Appendix $C$ of the full report. 


\section{ACKNOHLEDGEMENTS}

This document is the product of the collective efforts of a number of dedicated people who believe in the promise and future of geothermal energy as an important component of a secure, cost competitive, and environmentally compatible energy base for the United States, as well as for those many developing nations around the world which are fortunate enough to have the resource within their borders. The principal author was James Satrape of Meridian Corporation. He was responsible for shaping this report and spent many hours researching and writing to achieve this product. The following individuals contributed significantly in developing the information contained herein: Kerry Schwartz and Robert Blackett (country resource summaries), and Fadia Farrell (country by country demographic and economic data). Special thanks go to Jan Bowers, Claudia MacDonnell and Dr. Dennis Ford of Meridian Corporation; Jan for her assistance and hard work in reviewing and editing the final report, Claudia for her able coordination of the final production effort, and Dennis for managing the study effort and for ensuring high standards in the preparation of the report.

Mr. Robert Hendron of Los Alamos National Laboratory, Dr. John E. Mock and Marshal1 Reed of the U.S. Department of Energy, Geothermal Technology Division, and Deepak C. Kenkeremath of Meridian must receive special thanks for sharing their knowledge, insight, and perspectives with the project team in formulating this valuable resource document. 